\title{
DAMPAK REVOLUSI BUDAYA TERHADAP PENDIDIKAN ANAK DALAM PERSPEKTIF ISLAM
}

\author{
Muzamil \\ Dosen STAI Ma'had Aly Al-Hikam Malang \\ Muzammilzaini099@gmail.com
}

\begin{abstract}
Abstrak
Banyak perubahan atau revolusi budaya yang menghebohkan dan dinilai oleh banyak pihak, telah melanggar norma kesusilaan atau norma-norma agama sebenarnya merupakan potret lain dari kondisi masyarakat kita atau diri kita yang sedang retak, sedang terjerumus dalam desakralisasi agama dan pengabaian komitmen edukasi, khususnya terhadap anak. Anak tidak ubahnya sebagai obyek yang secara terus menerus menjadi korban para produsen budaya yang berwatak rakus dalam mengejar keuntungan ekonomi dan populeritas.
\end{abstract}

Kata Kunci: revolusi budaya, desakralisasi agama, anak Islam

\section{PENDAHULUAN}

Sudah demikian sering kita saksikan perubahan spektakuler di tengah masyarakat yang berkaitan dengan budaya atau gaya hidup manusia. Dalam ranah global, mausia menunjukkan keseriusannya dalam menghasilkan karyakarya yang berpengaruh besar terhadap perkembangan hidup manusia.

"Kebudayaan baru adalah kebudayaan yang membunuh umat manusia. Dan pembunuhan itu dilakukan dibalik selimut perdagangan. Cahaya Tuhan mereka renggut dari kalbu manusia" (Muhammad Iqbal). (Ibrahim, 1997)

Apa yang disampaikan lqbal tersebut menunjukkan, bahwa sudah demikian banyak perubahan yang mengandung virus dahsyat terhadap kehidupan manusia. Sikap manusia bermacam-macam terhadap perubahan itu. 
Keterkaitan dengan kepentingan dan kesenangan membuat perubahan terus terjadi, meski ada pengaruh yang potensial menghancurkannya.

Sudah terbukti, bahwa era globalisasi informasi mampu menyebarkan kekuatan dahsyat untuk mempengaruhi nalar, ideologi, sosial, budaya, dan bahkan nilai-nilai agama yang dipeluk dan semestinya harus dijalani manusia. Manusia yang semula dikenal taat beragama, bisa berubah menjadi pelanggar norma agama akibat perubahan yang mempengaruhinya. Di era sekarang ini, setiap pelaku agama telah berada dalam satu jendela dunia yang mudah untuk dijadikan sasaran kedahsyatan pengaruh informasi, yang tentu saja bermuatan, diantaranya ajakan untuk merubah asumsi, sikap, gaya hidup, dan berelasi sosialnya.

Pelaku agama di masing-masing bangsa tersebut menjadi sasaran pebisnis informasi global, karena di samping komunitas bisnis global ini berobsesi meraih keuntungan ekonomi, juga berkeinginan membangun tatananan dan kultur baru yang sesuai dengan kepentingan masyarakat global. Di sinilah bahayanya, karena akan banyak kemungkinan terjadi, diantaranya terpengaruh dan tercerabutnya akar-akar keagamaan dalam diri manusia dan pelaku agama akibat menyerahkan dirinya menjadi budak perubahan kultur global.

Pakar bidang masa depan, Sardar (1988) menyatakan, bahwa bagi dunia muslim, revolusi informasi menghadirkan tantangan-tantangan khusus yang harus diatasi demi kelangsungan hidup fisik maupun budaya umat. Tidak jarang tantangan-tantangan ini merupakan dilemma utama: haruskah negeri-negeri muslim menganut suatu teknologi yang kompulsif dan totaliter, dengan resiko timbulnya ketergantungan baru yang lebih subversif dan menghancurkan.

Pola perilaku berjenis desakralisasi agama merupakan produk anak zaman yang sedang terseret oleh rotasi dinamika dan gelombang desakan besar kepentingan hidup manusia sendiri yang sedang didewakan atau dikultuskannya melebihi wilayah moral yang sudah dipondasikan oleh agama. Agama menjadi tidak lebih dari kumpulan doktrin kosong yang kehilangan makna (meaningless) akibat dikalahkan oleh desakan kuat kepentingan duniawi yang sedang dipanglimakan manusia.

Akibat atau dampak perilaku manusia yang bercorak demikian itulah, yang diantaranya potret kehidupan manusia terasa mengidap apa yang 
disebut oleh Sosiolog kenamaan Kazuo Shimogagi dengan "nihilisme total", artinya potret kehidupan manusia ini seperti wajah dunia tak terkendali, tidak punya nyawa yang menghidupkan, terasa tidak punya baju moralitas, dan gampang membenarkan kekejaman, penderitaan, penindasan, penelanjangan norma, dan berbagai bentuk eksploitasi manusia atas manusia. Manusia yang terkena dampaknya dapat mengalami keterasingan psikologis yang luar biasa, apalagi anak. Anak bisa terjerumus dalam kondisi mengenaskan akibat perubahan budaya yang mempengaruhinya.

\section{PEMBAHASAN}

Pendidikan Islam Dan Perilaku Manusia

Wajah masyarakat seperti dalam desskripsi pendahuluan itu dapat terbaca dalam kehidupan masyarakat sekuleristik dan hedonistik, karena di masyarakat demikian ini, tingkat penghargaan manusia terhadap norma sangatlah rendah, sementara di sisi lain, berbagai bentuk perilaku yang bercorak animalisasi atau pembinatangan manusia sangat ditoleransi dan bahkan dikultuskannya.

Banyak manusia yang terjerumus dalam kesalahan. Tidak sedikit diantranya yang memahami kalau yang dilakukannya melebihi apa yang diperbuat oleh binatang. Bentuk pembinatangan manusia dapatlah berupa penegasian dan pendistorsian harkat kemanusiaan, menjerumuskan sesama sebagai obyek komoditi dan komersialisasi, seperti menghilangkan kecerdasan nurani, kebebasan nalar, dan nilai-nilai moralitas untuk dipertaruhkan dalam transaksi bercorak penelanjangan dan kriminalisasi aurat, mengeliminasi sakralitas aurat dan jati diri keagamaan demi obsesi karier, fantasi gaya hidup, kepuasan emosionalitas, dan kesenangan biologis.

Hal itu menunjukkan tentang perilaku manusia yang bermacammacam. Salah satu jenis perilakunya adalah perilaku yang merugikan diri dan sesama manusia atau lingkungan pergaulannya. Meski demikian, banyak yang terjerumus, diantaranya anak, yang menilai kalau tawaran kehidupan hedonistik lebih menyenangkan dan menguntungkan.

Obsesi-obsesi bercorak hedonistik tersebut pernah dikritik oleh Abdurrahim (1993), bahwa tuhan modern itu ada tiga, pertama, tuhan 
tahta, kedua, tuhan wanita, dan ketiga, tuhan harta. Ketiga tuhan ini telah menjelma menjadi obsesi dan ambisi yang meracuni serta menjajah nurani manusia. Manusia mudah takluk, menyerah, dan jadi robot akibat dikuasai oleh tuhan-tuhan yang diberhalakannya ini. Manusia akhirnya gagal jadi pelaku sejarah yang cerdas akibat dirinya menghamba pada kepentingan kekuasaan, eksotisme perempuan dan kekuatan kapitalisme.

Ketika eksotisme perempuan misalnya memasuki atau bertali-temali dengan kepentingan kapitalisme seperti industrialisasi seks, komoditi tubuh, "bisnis birahi", dan pembenaran dimensi keindahan pornografi sebagai seni, maka komoditi atau eksploitasi perempuan, yang nota bene sekarang disebut sebagai pasar global eksotisme, erotisme dan hedonisme gaya hidup, maka tidak pelak lagi perempuan dan harta berhasil menjadi dua kekuatan yang menyatu sebagai tuhannya atau "agamanya" masyarakat sekuler yang edan.

Tuhan lain atau "tuhan tandingan" yang paling popular di zaman modern ini adalah duit, karena memang ternyata duit ini termasuk "ilah" yang paling berkuasa di dunia ini. Di kalangan orang Amerika terkenal istilah "The Almighty Dollar" (Dollar yang maha kuasa). Memang telah ternyata di dunia, bahwa hampir semua yang ada di dalam hidup ini dapat diperoleh dengan duit, bahkan dalam banyak hal, harga diri manusiapun bisa dibeli dengan duit. Cobalah lihat sekitar kita sekarang ini, hampir semuanya ada "harganya", jadi bisa dibeli dengan duit. Manusia tidak malu lagi melakukan apa saja demi untuk mendapatkan duit, padahal malu itu salah satu bagian terpenting dari iman. Betapa banyak orang yang sampai hati menggadaikan negeri dan bangsanya sendiri demi mendapatkan duit. (Abdurrahim, 1993)

Sebagai indikasi, kecenderungan negatif di negeri ini adalah menguatnya revolusi gaya hidup, setidaknya pergeseran kultural masyarakat yang semakin eksotik. Desakralisasi agama telah menjadi model yang dikedepankan sebagai berhala kontemporer. Oleh komunitas pebisnis hiburan atau budaya yang bersifat sekuleristik, negeri ini didesain sebagai "keranjang sampah" , suatu negeri yang lebih tampak jadi lahan komoditi budaya yang menghalalkan penelanjangan nilai-nilai religiusitas.

Dunia pendidikan yang idealitasnya menjadi tempat melindungi anak, justru kurang mampu menunjukkan kekuatannya, apalagi pola-pola pendidikan yang terfokus menempatkan anak sebagai obyek kapitalisme atau 
kebijakan-kebijakan eksklsifnya, sehingga anak dalam ranah penyelenggaraan pendidikan demikian, lebih sering kehilangan jati dirinya.

Eksistensi agama dewasa ini terbaca sedang dikalahkan oleh tampilnya berhala-berhala kontemporer berupa jagad hiburan misalnya yang menampilkan adegan-adegan seronok dan eksploitasi perempuan dengan modus penanggalan nilai-nilai moralitas. Perempuan dijadikan sebagai obyek menarik minat konsumen dengan cara mendistorsikan kesucian agama. Kesucian agama langit dikalahkan oleh komoditi gaya hidup yang berbasis kapitalisme dan hedonisme. Perempuan telah dijadikan alat pembesaran bisnis kalangan pemilik modal, pecandu hiburan, dan pengeliminasi nilai-nilai keagamaan.

Oleh kaum pebisnis hiburan, komunitas pemeluk agama, serta khususnya kalangan penyelenggara pendidikan ini sedang diajak dan dicekoki agar berlomba jadi pegiat atau pengembang desakralisasi agama, penabur kemaksiatan, dan pembenar angkara di era globalisasi budaya ini.

Perlu kita baca, bahwa salah satu kata yang sedang "in" masa kini adalah kata "global, atau sejagad-raya. Dunia dewasa ini sedang diwarnai oleh global politics, global technology, global economy, global market, dan global strategy. Bahkan bumi tempat kita berada pun tidak terlepas dari prediket global, yakni global village. (Alwi Shihab, 1997)

Problem globalisasi tidak bisa dianggap ringan, apalagi berkaitan dengan revolusi budaya. Problem globalisasi ini diniscayakan menuntut dan menantang setiap warga bangsa di muka bumi, tidak terkecuali di Indonesia, untuk mampu membaca dan memahaminya, serta menjadi bagian dari perubahan yang terjadi.

Tuntutan demikian itu jelas berhubungan dengan masalah kualitas diri manusia Indonesia. Standarisasi kualitas manusia Indonesia ini, sebagaimana umumnya bangsa-bangsa di muka bumi, adalah ditentukan melalui pendidikan yang diterapkan atau diimplementasikannya.

Komaruddin Hidayat (2006) pun mengingatkan: belajar dari berbagai negara yang tergolong maju, setidaknya ada dua pelajaran penting yang harus menjadi pelajaran bagi bangsa Indonesia, yaitu harus menciptakan pemerintahan yang bersih dan pendidikan yang bagus (clean governance and good education). Bila kedua hal ini dikesampingkan, sebagaimana yang kita 
rasakan dan saksikan selama ini, maka berbagai bentuk problem berat, termasuk diantaranya yang berhubungan dengan ujian terhadap pendidikan anak di tanah air marak terjadi. (Tholhah Hasan, 2010)

Mereka "mendidik" masyarakat Indonesia, yang berjuluk the biggest moeslem community in the world supaya menjadi masyarakat yang berani berseberangan dengan agamanya, mendistorsi kesuciannya, dan menghilangkan keberdayaannya. Mereka dibentuk oleh perubahan budaya global supaya apa yang dijalankannya sesuai dengan panggilan kepentingankepentingan politik eksklsif, yag membuat perspektif publik bisa mengasumsiannya bahwa sudah terjadi pemerataan kejahatan dimanamana.

Padahal namanya juga agama, yang oleh Max Weber disebut sebagai kanopi suci, yang idealnya harus menjadi pijakan dan pengayom harkat kemanusiaan, maka tentu saja wajah jagad pergulatan hidup manusia menjadi sarat noktah tatkala manusia berlomba terlibat dalam praktikpraktik pembusukan moral (moral decay). Pemberangusan atau pelecehan moral ini telah hadir dalam bentuk produk-produk budaya yang berlawanan dengan doktrin-doktrin ajaran Islam, khususnya doktrin edukasi yang bersifat membebaskan yang digariskan dalam ajaran Islam.

Perspektif Islam

Perubahan budaya yang telah membawa dampak serius terhadap kehidupan masyarakat, keluarga, khususnya anak, jelas merupakan perubahan yang bisa dikategorikan sebagai perubahan yang menyesatkan dan menghancurkan. Sehingga dalam Islam, perubahan demikian terlarang. Beragamnya perubahan kemaksiatan atau kebejatan yang terjadi di tengah masyarakat tidak boleh dianggap remeh oleh umat Islam, apalagi para penyelenggara pendidikan di linkungan keluarga. Anak yang berposisi sebagai subyek dalam pendidikan keluarga, merupakan sosok yang mendapatkan perhatian besar dari Islam.

Islam menghargai setiap upaya yang bersifat positip terhadap pembentukan atau pembinaan anak. Di sisi lain, Islam juga mengutuk atau melarang keras praktik-praktik perbuatan yang bercorak menghancurkan atau membuat anak kehilangan jati dirinya. 
Diingatkan oleh Nabi Muhammad SAW Semua umatku dimaafkan kesalahannya kecuali orang-orang yang berterang-terangan (secara terbuka) berbuat maksiat. Dan sungguh tidak tahu malu apabila ada orang melakukan maksiat di waktu malam yang tidak ketahuan orang (karena ditutupi Allah), kemudian pada waktu pagi ia berkata "aku telah berbuat demikian dan demikian", sehingga ia membuka tutup Allah dari dirinya, padahal semalaman suntuk Tuhannya telah menutupinya".

Hadis tersebut menunjukkan bahwa ada jenis perbuatan tercela berupa demontrasi kemasiatan, pamer aurat, bisnis aurat, atau kapitalisme seksual yang dikemas dengan model penyemaian dunia hiburan, seni, dan apa saja yang dinilai layak jual dan konsumsi publik..

Misalnya aurat perempuan akan tetap suci dan menjadi sumber kekuatan yang mengharumkan bangsa, apalagi anak-anak peremuan bangsa jika tetap terjaga kesuciannya, namun sebaliknya, akan menjadi malapetaka yang menodai keberlanjutan hidup bangsa, khususnya keluarga bilamana kita membiarkannya menjadi obyek komoditi produsen kemaksiatan.

Pendidikan di Indonesia sebagaimana misalnya sebagaimana kata Muhajir, sudah mendesak untuk menerapkan pendiidikan progresif dan bukan pendidikan yang bercorak kapitalisme dan diskriminasi, karena dengan pendidikan progresif, masyarakat didik atau peserta didik akan lebih terfokus memikirkan tentang pendidikan untuk bangsa dan Indonesia, dan bukan pendidikan untuk menjadi jalan mewujudkan kepentingan peribadi, keluarga, dan golongannya semata (Setianingsih, 2008). Hal ini jelas, bahwa pendidikan harus menguatkan kepribadian anak, dan bukan membuat anak menjadi lemah.

Harus ada keberanian dari masyarakat kita untuk menjadikan kemaksiatan atau krimnalitas budaya sebagai musuh bersama (common enemy) yang diperangi atau djadikan obyek jihadnya. Begitu mencuat ada bisnis yang bercorak "abu-abu" atau kecenderungan kapitalisme aurat perempuan, maka secepatnya kita melakukan reaksi keras dan bahkan radikal.

Kalau kita bersifat pasip atau "membisukan" diri dengan fenomena patologi sosial tersebut, maka kita akan terus dicekoki dan digiring sebagai 
konsumen pasip yang diasumsikan selalu menyetujui dengan bisnis kemaksiatan lainnya.

"Engkau adalah sebaik-baik golongan (masyarakat) yang dihadirkan di antara manusia untuk mengamalkan kebaikan dan mencegah kemungkaran" (Ali Imran, 110), adalah firman Allah yang menunjukkan bahwa hidup manusia ini layaknya sebagai "rasul" yang punya tugas ganda, pertama, menabur kebaikan di muka bumi, dan kedua, berjuang di jalan kebenaran untuk mencegah dan menghalau praktik-praktik kejahatan, kekejian, dan beragam kemunkaran.

Tugas yang dipercayakan kepada segmen masyarakat tersebut mengisyaratkan, bahwa potret sejarah perjalanan hidup manusia sulit steril dari berbagai bentuk perilaku yang disnormatif, berlawanan dengan norma agama, atau bermoduskan anomali dan malversasi, sehingga jika menginginkan terjadinya kondisi pencerahan haruslah ada pelaku sejarah yang berdiri di garis kebajikan.

Tampilnya pelaku sejarah yang punya komitmen kuat terhadap pembaharuan dan bahkan dekonstruksi terhadap praktik-praktik kemunkaran serta pembusukan nilai-nilai (values decay) memang merupakan kebutuhan yang selalu harus eksis, sebab jika tidak, potret kehidupan masyarakat akan lebih buruk dan bukan tidak mungkin akan bertaburan pola perilaku berjenis desakralisasi agama.

\section{KESIMPULAN}

Berdasarkan uraian tersebut, dapatlah disimpulkan, bahwa tidak sedikit perubahan budaya atau gaya hidup yang telah melanggar norma kesusilaan atau norma agama. Mereka yang memproduk budaya ini telah terjerumus dalam desakralisasi agama dan pengabaian norma-norma kepatutan. Dampak mengerikan dari perilaku ini adalah terhaap keberlanjutan hidup dan kependidikan anak. Anak tidak ubahnya sebagai obyek yang kehilangan peluang progreifitasnya akibat terus menerus digelontor oleh budaya yang mengajaknya menjadi pelaku-pelaku antagonistik. 


\section{DAFTAR RUJUKAN}

Abdurrahim. Muhammad Imaduddin, 1999. Kuliah Tauhid. Jakarta: Yayasan Pembina Sari Insan.

Ibrahim. Idi Subandy. 1997. Ecstasy Gaya Hidup, Kebudayaan Pop dalam Masyarakat Komoditas Indonesia. Bandung: Mizan.

Hasan, Muhammad Tholhah, 2000, Islam dalam Perspektif Sosial Budaya, Jakarta: Galasa Nusantara.

Sardar. Ziauddin. 1988. Tantangan Dunia Islam Abad 21, Menjangkau Informasi, Bandung: Mizan.

Setianingsih, Pemikiran Pendidikan Islam dalam Kajian Pemikiran Mohammad Tholchah Hasan, makalah, 2 April 2008

Shihab, Alwi. 1997, Islam Inklusif, Menuju Sikap Terbuka dalam Beragama, Bandung: Mizan. 